Relations industrielles

Industrial Relations

\title{
Apprenticeship and Statistics
}

\section{Charles E. Thérien}

Volume 6, numéro 1, décembre 1950

URI : https://id.erudit.org/iderudit/1023259ar

DOI : https://doi.org/10.7202/1023259ar

Aller au sommaire du numéro

Éditeur(s)

Département des relations industrielles de l'Université Laval

ISSN

0034-379X (imprimé)

1703-8138 (numérique)

Découvrir la revue

Citer cet article

Thérien, C. (1950). Apprenticeship and Statistics. Relations industrielles /

Industrial Relations, 6(1), 26-27. https://doi.org/10.7202/1023259ar

Tous droits réservés @ C Département des relations industrielles de l’Université Laval, 1950
Ce document est protégé par la loi sur le droit d'auteur. L'utilisation des services d'Érudit (y compris la reproduction) est assujettie à sa politique d'utilisation que vous pouvez consulter en ligne.

https://apropos.erudit.org/fr/usagers/politique-dutilisation/ 


\section{Publications received}

BAKER, Helen, Transmitting information through management \& union channels; two case studies. Princeton University, Department of Economics.

CARTWRIGHT, Philip W., Guaranteed Flans and the Level and Stability of Income. University of Washington. Reprinted from the Twenty-fourth Annual Proceedings of the Pacific Coast Economic Association.

The Foreman's Place in Management, Research Bulletin No. 2, July, 1950. LaborManagement Institute, University of Connecticut, Storrs, Connecticut.

The economics of Collective bargaining. Proceedings of a Series of Public Lectures held during 1948 and 1949 in Berkeley and Los Angeles. Institute of Industrial Relations, University of California.

How to run a union meeting. A simple manual on parliamentary Law. 56 pages. Workers Education Bureau of America, 1440 Broadway, New York 18, N.Y.

KASTNER, Rexford P., Seniority Rights for Supervisors? Research Bulletin No. 7, Sept. 1950. New York State School of Industrial and Labor Relations, Cornell University.

Pension Plan Financing, Mimeograph Bulletin No. 3, May 1950, Labor-Management Institute, University of Connecticut, Storrs, Connecticut.

RANDALL, Roger L., Labor Agreements in the West Coast fishing Industry: restraint of trade or basis of Industrial Stability? Reprint No. 24. 1950, 201 California Hall, University of California, Berkeley 4, Cal.

Syndicat - Force ouvrière! Publié par le service d'éducation de la C.T.C.C. Août $1950-23$ pages.

Union Service Institute. July 30 - Aug. 4. Institute of Labor Economics and the Office of Short Courses and Conferences, University of Washington, Seattle.

The Union Steward and his Job. Research Bulletin No. 1 - January 1950. Labor-Management Institute, University of Connecticut. Storrs, Connecticut.

Man becomes great exactly in the degree in which he works for the welfare of his fellow-men.

Mahatma Gandhi
Apprenticeship and Statistics

Charles e. Thérien,

Statistician, Building Trades Apprenticeship

Commission of Montreal

The Apprenticeship Assistance Act, of the Province of Quebec, assented to May 24,1945 , sets forth an apprenticeship formula which appears by far superior to the average. Its merit, no doubt, stems from the fact that its origin lies in the tripartite cooperation of capital, labour and the state. This plan, leaving the direction of apprenticeship to industry under the supervision of the state, has already proved its worth.

Indeed, in less than two years more than fifteen apprenticeship commissions were established in all corners of the Province. Apprenticeship schools were opened and the training of apprentices was begun.

In the region of Montreal alone, the Building Trades Apprenticeship Commission has trained over 3,500 apprentices and journeymen since the opening of its center. The table below illustrates in a concrete manner the activities of this center.

We may well remark that the system of apprenticeship of the Province has already borne fruit and we have reason to rejoice. However, it is possible to render it still more productive by perfecting it. One of the drawbacks to the healthy development of our system today is the lack of statistics and essential data.

In order to direct the training of our apprentices in a reasonable fashion, we must first become acquainted with the manpower needs of industry from the statistical point of view; secondly, we must keep in sight the number of apprentices we are training in our centers.

With the aid of this basic information, it will be much easier to develop a training program for apprentices according to a system based on the actual needs of industry and on an exact knowledge of the productive capacity of our apprenticeship centers.

It is, therefore, absolutely necessary that all those concerned with the question of apprenticeship freely furnish their active cooperation in this fleld. It is of first importance that employers and union leaders, as well as the members of apprenticeship commissions and parity committees concerned, make it their duty to supply the different bureaus of statistics with these data so vital to the cause of apprenticeship. In so doing, all will substantially aid to perfect it. 


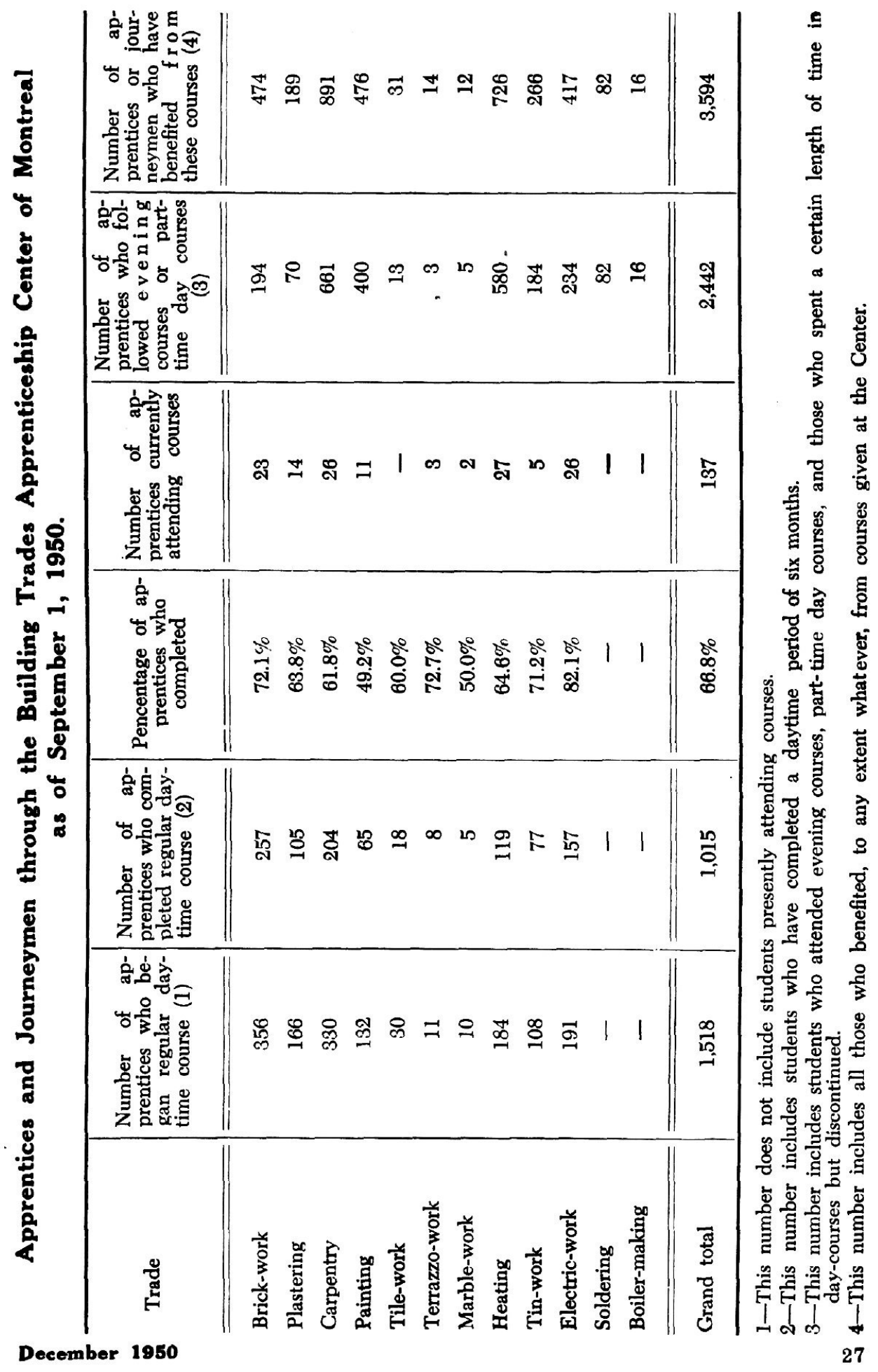

